ScIDice

\section{Repeatability Of Visual, Spectrophotometer And Intraoral Scanner Methods In Shade Matching: A Comparative In-Vivo Study \\ Research Article}

Mohamed Fattouh ${ }^{1,4 *}$, Laila M M Kenawi ${ }^{2,4}$, Omar A Aboelela ${ }^{3,4}$

${ }^{1}$ Fixed Prosthodontics Department, Faculty of Dentistry, Cairo University, Cairo, Egypt.

${ }^{2}$ Department of Endodontics, Faculty of Dentistry, Cairo University, Cairo, Egypt.

${ }^{3}$ Lecturer, Crown and Bridge department, Faculty of Dentistry, Suez Canal University, Ismailia, Egypt.

${ }^{4}$ Assistant Professor, Faculty of Dentistry, Umm Al-Qura University, Makkah, Saudi Arabia.

\title{
Abstract
}

Introduction: Visual method of shade determination is highly subjective and a cause of concern for dentists. Instrumental methods were used to determine tooth shade hoping to achieve superior esthetics. Great controversy still exist about the best method and its repeatability for shade selection.

Objective: To compare and measure repeatability of three methods of shade determination, i.e.: visual, spectrophotometer, and intraoral scanner methods by three groups with different experience level.

Materials and Methods: Fifty participantswith intact maxillary incisor teeth were selected. Thirty evaluators with different experience level (6th year students, less than 2 years' experience and prosthodontists) evaluated teeth shade. The shade of middle third of right maxillary central incisors were recorded using visual, spectrophotometric and intraoral scanners methods. Tooth color records (VITA 3D shade and $\mathrm{L}^{*} \mathrm{a}^{*} \mathrm{~b}^{*}$ values) were collected, the average repeatability of each evaluator and each method were tabulated and subjected to suitable statistical analysis.

Results: Instrumental methods were more repeatable than visual methods. Intraoral scanner (Trios 3) recorded better repeatability $(94 \%)$ than VITA Easyshade Advance spectrophotometer (93\%) but the difference was statistically non-significant. when comparing the three methods, a statistically significant proportion of agreement between both [ visual and spectrophotometric method $(\mathrm{P}<0.01)$ ] and [the visual and intraoral scanner method $(\mathrm{P}<0.01)$ ] with high percentage of agreements "yes". In the visual method, the prosthodontists records were more repeatable $(84.16 \%)$ followed by dentist with less than 2 years' experience $(83.8 \%)$ then thestudents $(81.5 \%)$, but the difference was not statistically significant.

Conclusion: Instrumental methods for shade selection using spectrophotometer or intraoral scanner were more repeatable than the visual method. Trios 3 intraoral scanner showed higher repeatability than Easy shade spectrophotometer. Visual shade repeatability was influenced by the operator's experience.

Keywords: Spectrophotometer; Intraoral Scanner; Easyshade Advance; Trios 3; Tooth Color; Shade Matching.

\section{Introduction}

Color selection of natural teeth is a Challenging step in fixed prosthodontics as many restorations failed due to improper color choice. Final shade of the restoration should match natural tooth especially in the anterior region [1]. Shade determination can be carried out by two methods: visual method with commercial shade tabs or instrumental method by using a colorimeter, digital cameras, spectrophotometer and recently by intraoral scanners [2-4].
There are three-color systems that provides the standard principles for color analysis. Munsell color system involves a number of colored chips for visual color matching, arranged in three dimensions of appearance: (V: value), (H: hue), and (C: chroma). The CIELAB color space (also famous as CIE L*a*b*) identifies color as the following three values: $\mathrm{L}^{*}$ for the lightness and it corresponds to (Value) in Munsell system, $\mathrm{a}^{*}$ from green (negative) to red (positive), and $b^{*}$ for blue (negative) to yellow (positive) [5]. It describes color properties freely from an established image. The CIELAB color space is classically used when illustrations for print

\section{*Corresponding Author:}

Dr. Mohamed Fattouh,

Faculty of Dentistry, Umm Al-Qura University, P.O. Box 715, Makkah 24238, Saudi Arabia.

Tel: $00966592771003-00201005119793$

Email ID: mohamed.fattouh@dentistry.cu.edu.eg

Received: April 17, 2021

Accepted: May 03, 2021

Published: May 11, 2021

Citation: Mohamed Fattouh, Laila M M Kenawi, Omar A Aboelela. Repeatability Of Visual, Spectrophotometer And Intraoral Scanner Methods In Shade Matching: A Comparative In-Vivo Study. Int J Dentistry Oral Sci. 2021;08(5):2439-2445. doi: http://dx.doi.org/10.19070/2377-8075-21000480

Copyright: Mohamed Fattouh ${ }^{\circ} 2021$. This is an open-access article distributed under the terms of the Creative Commons Attribution License, which permits unrestricted use, distribution and reproduction in any medium, provided the original author and source are credited. 
have to be changed from red green blue (RGB) to CMYK color models [6]. The CIELCH is the third color space, the $\mathrm{C}^{*}$ identifies chroma and $\mathrm{h}^{\circ}$ means hue angle for angular assessment. CIELCH color system isrelated to physical samples established on Munsell color scale [7]. CIE L*a*b* represents-according to Pecho et al. [8] - the most accurate tool for color evaluation in dentistry. The most popular method of shade determination is visual comparison usingshade guide as Shofu Vintage shade guide, IvoclarVivadent Chromascop, Dentsply Portrait IPN shade guide, Vitapan Classical, and VITA 3D-Master,however this method is highly subjective and depends on multiple variables as age of the dentist and his color perception, illumination,background, optical illusion, intensity of light source and angle of incidence [9].VITA 3D-master shade guide is the most commonly used visual method, considering the three parameters of color: hue, chroma, and valueIt gives standardized and superior color selection [10]. In a study carried by Pohlen et al. [11], VITA 3D-master shade guide system recorded best shade matching results with more standard color difference than other shade guides. VITA3D-master shade guide has more ordered color distribution and higher color match than other shade tabs. Electronic method significantly decreases subjective errors of the visual shade guides. Electronic devices that are used to determine teeth shade are ShadeScan (digital camera with colorimeter, Cynovad, Canada), VITAEasyshade (spectrophotometer, Vident, Brea, CA, USA), ShadeVision (digital camera with colorimeter, X-Rite America, Inc., Grand Rapids, Michigan, USA) and Spectroshade (spectrophotometer, MHT Optic Research AG, Niederhasli, Switzerland) [4]. VITA Easyshade Advance 4.0 (VITA Zahnfabrik, Bad Säckingen, Germany) is a contact spectrophotometer, its probe is held at $90^{\circ}$ on labial surface of the selected tooth [12]. It has a standardized built-in illumination that isn't affected by surrounding illumination, making its readings unaffected by surrounding moreover, it measures the light energy returned from the tooth at $25 \mathrm{~nm}$ intervals across the visible spectrum [13]. Trios 3 Intraoral scanner (3Shape, Copenhagen, Denmark) had been used to record colored images and distinguish between soft and hard tissue structures [2] where, the light is projected to the teeth and then reflected to internal sensor and managed by the scanner software to generate an image from the scanned parts [14], shade matching is carried by LED light, high-definition camera , computer software and it is based on VITA shade guide [15]. The evaluator's experience may play an important role in shade matching, Della Bona et al. [16] reported significant relationship between visual and the instrumental methodswhen the dentists were experienced. Others support this idea in researches carried out in different circumstances [9, 17-19], but Kröger et al. [20] stated that experience had minimal role and of no practical importance in shade selection between different groups with variable experiences. Other researches [21-23] supported this conclusion, arguing that when using the VITA 3Dmaster shade guide, dentist's experience was not an effectiveelement in the selection of teeth shade.

The aim of this in vivo study was to compare the color matching of maxillarycentral incisor using visual method (VITA 3D-master shade guide) and instrumental methods using VITA Easyshade and Trios 3. The null hypothesis was that there would not be a significant difference between the shade matching methods as well as the three groups of evaluators.

\section{Materials And Methods}

Sample size was calculated according to previous published studies $[11,16,24]$, fifty participants representing $80 \%$ power to detect a difference between means and $\alpha=0.05$,to be able to detect significant differencesin results, sample size was calculated using power analysis software (G*Power). This study was performed in Fixed Prosthodontics Department clinics of Faculty of Dentistry, Umm Alqura University, Makkah, Saudi Arabia. The Research Ethics Committee of Umm Alqura University approved the study protocol (Approval number: HAPO-02-K-012-2021-04-660). A written informed consent describing the treatment plan, photos' publishing, and collection of results was signed by each participant.

\section{Participants' selection}

Shade matching procedures were performed on50 participants , Inclusion criteria were: Age range from 20 to 35 years with intact maxillary incisor teeth with no history of endodontic treatment, any conservative or prosthetic restorations and with healthy periodontal tissue, The exclusion criteria are 1) having teeth that have been bleachedbefore 2) usage of medication 3) Presence of a systemic disease 4) a history of taking antibiotics during childhood or fever disease.

\section{Evaluators' classification}

Evaluators of tooth shadewereclassified into three groups according to their experience level. The first group (10 evaluators) involved 6th year dental students from Faculty of Dentistry, Umm Alqura University, the second group (10 evaluators) involved dentist with less than two years $(<2)$ of experience and the third group involved 10 prosthodontists. All evaluators were checked for any color vision impairments using the Ishihara color vision test [25]. Evaluators with any kind of visual deficiency were excluded from the study. They were trained on the proper usage of the VITA3D-master shade guide, VITA Easy shade and Trios 3 according to the shade guide's and machine's instruction manuals.

\section{Shade matching procedures}

The tooth selected for shade matching was the maxillary right central incisor. After cleaning and polishing the teeth, shade recordings were done for middle third of maxillary right central incisor using three different methods: 1- Visual evaluation using VITA 3D-master shade guide, 2- Spectrophotometric evaluation using VITA Easyshade Advance, 3- intraoral scanner evaluation using Trios 3 intraoral scanner. Matching procedureswas done between 11:00 AM and 1.00 PM [26] with dental chair directed toward North and facing sunlight. Each participant sit in upright position at the same level from the evaluator's eyes, $40 \mathrm{~cm}$. away from the evaluator, with elimination of all bright colors as (lipstick, tinted eye glasses).In between every measurement, each evaluator re-adapted his eye by looking at a blue paper for five seconds to prevent eye fatigue [27].

\section{Visual shade selection}

The VITA 3D-Master shade guide (VITA Zahnfabrik, Bad Säckingen, Germany) was used for the visual shade selection method 
(Figure 1). It uses the accepted color perception concepts of hue, value and chroma where the first number represent value (lightness) then the letter represents hue and final number denotes chroma. For every participant, the suitable shade was selected based on the matching tab.

\section{Spectrophotometer shade selection}

A Clinical Spectrophotometer (VITA Easyshade Advance, VITA Zahnfabrik, BadSäckingen, Germany) was used (Figure 2). The manufacturer's instructions were followed for shade recordings wherethe Instrument probe tip was positioned on the middle third of the upper right central incisor. The "Tooth single"program was chosen for recording the shade and the $L^{*} a^{*} b^{*}$ values of the tooth.

\section{Intraoral Scanner shade selection}

An intraoral scanner (Trios 3, 3Shape, Copenhagen, Denmark) was used to scan maxillary right incisor from the incisal, vestibular and palatal aspects, when the arch image was showed on the screen, the "shade icon" wasapplied to the labial third of the toothto determine theshade.

VITA Easyshade Advance and Trios 3 were calibrated before scanning each tooth. The 3D-Master reference recorded by the three methods was transformed into $\mathrm{L}^{*}, \mathrm{a}^{*}$ and $\mathrm{b}^{*}$ values using the table assumed by Alshiddi et al. [17].

\section{Data collection and statistical analysis}

Collected data from the three methods were recorded. The average repeatability and standard deviation (SD) of each evaluator and each method were tabulated in Microsoft Excel sheet, each dimension was considered individually. For the statistical analysis, Statistical Package for the Social Sciences (SPSS version 22.0, IBM Corporation, New York, USA) was used to analyze the repeatability of each method. To analyze the repeatability of each shade recording method, Analysis of variance (ANOVA) test was carried out. Also, ANOVA test was used to evaluate the statistical significance difference of the evaluator groups and to evaluate which group of evaluator fulfilled a higher repeatability.Agreement coefficient was tested between visual and spectrophotometric methods using Cohen's Kappa test. Agreement between visual and spectrophotometric methods as well as between visual and intraoral scanner methods was tested using $z$-test for proportions. In all tests, $(\mathrm{P}<0.05)$ was considered to be statistically significant.

\section{Results}

Tooth color records (VITA 3D shade and $\mathrm{L}^{*} \mathrm{a}^{*} \mathrm{~b}^{*}$ values) were collected by the mean visual, spectrophotometer and intraoral

Figure 1. Visual shade selection using VITA 3D-Master shade guide.

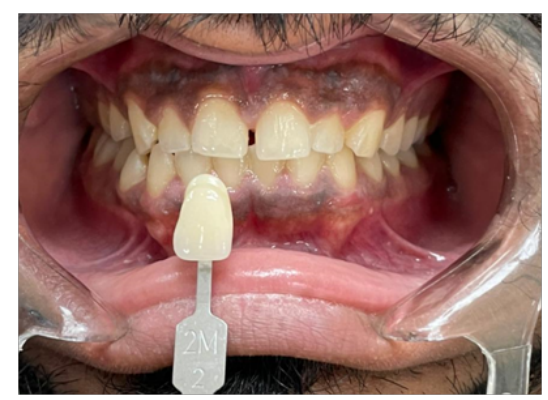

Figure 2. Spectrophotometric shade selection using VITA Easyshade Advance.

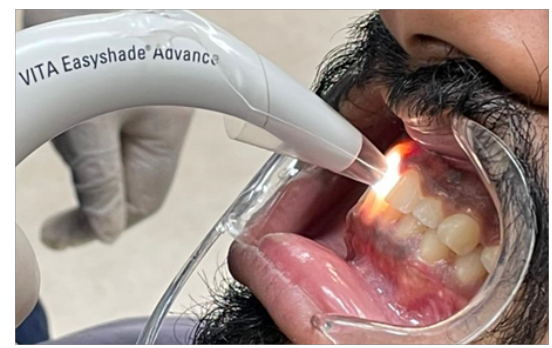

Figure 3. Repeatability of different shade matching methods.

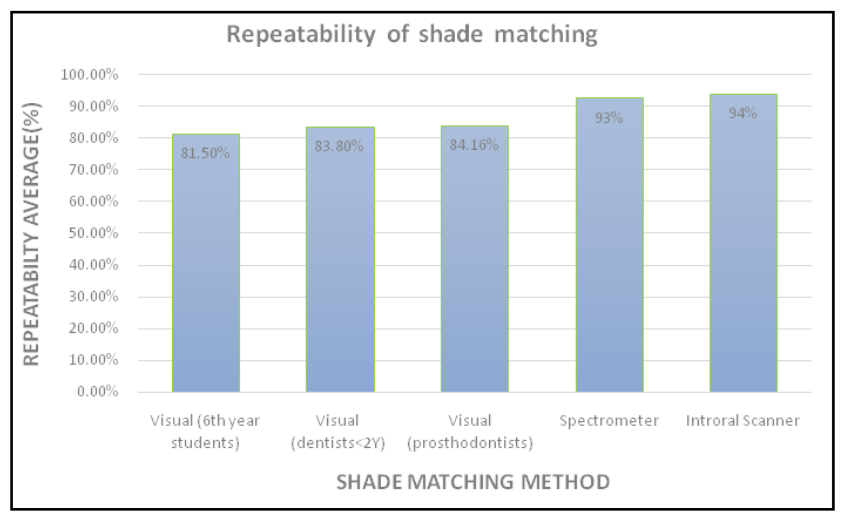


Table 1. Results of shade selection for all participants.

\begin{tabular}{|c|c|c|c|c|c|c|c|c|}
\hline \multirow[t]{2}{*}{$\begin{array}{c}\text { Par- } \\
\text { ticipant } \\
\text { number }\end{array}$} & \multirow[t]{2}{*}{ Shade } & \multirow[t]{2}{*}{$\begin{array}{l}\text { Visual by } \\
\text { Group } 1 \\
\text { (student) }\end{array}$} & \multirow[t]{2}{*}{$\begin{array}{c}\text { Visual by } \\
\text { Gp } 2 \\
(<2 Y)\end{array}$} & \multirow[t]{2}{*}{\begin{tabular}{|c|} 
Visual by \\
Gp3(Prosth- \\
odontist)
\end{tabular}} & \multirow{2}{*}{$\begin{array}{c}\begin{array}{c}\text { Spectropho- } \\
\text { tometer (Easy- } \\
\text { shade) }\end{array} \\
\mathrm{L}^{*} \mathrm{~b}^{*} \mathrm{a}^{*} \\
\end{array}$} & \multirow{2}{*}{$\begin{array}{c}\begin{array}{c}\text { Intraoral Scanner } \\
\text { (Trios 3) }\end{array} \\
\mathrm{L}^{*} \mathrm{~b}^{*} \mathrm{a}^{*}\end{array}$} & \multirow{2}{*}{$\begin{array}{l}\text { Agreement be- } \\
\text { tween mean Visual } \\
\text { method, Spectro- } \\
\text { photo-meter }\end{array}$} & \multirow{2}{*}{$\begin{array}{c}\text { Agreement } \\
\text { between mean } \\
\text { Visual method, } \\
\text { Intraoral scanner }\end{array}$} \\
\hline & & & & & & & & \\
\hline 1 & $2 \mathrm{M} 3$ & $3 \mathrm{M} 2$ & $2 \mathrm{M} 3$ & $2 \mathrm{M} 3$ & 84.33 .533 .4 & 83.53 .129 .5 & Yes & No \\
\hline 2 & $4 \mathrm{M} 2$ & $4 \mathrm{M} 2$ & $4 \mathrm{M} 2$ & $4 \mathrm{M} 2$ & 683.125 & 67.32 .727 & Yes & No \\
\hline 3 & $3 \mathrm{M} 2$ & $2 \mathrm{M} 3$ & $3 \mathrm{M} 2$ & $3 \mathrm{M} 2$ & $78.6-1.712 .7$ & $78-1.712 .5$ & Yes & Yes \\
\hline 4 & 2L2.5 & 2L2.5 & 2L2.5 & 2L2.5 & $81.7-1.418$ & $80.3-1.516 .3$ & Yes & Yes \\
\hline 5 & $2 \mathrm{M} 2$ & $2 \mathrm{M} 2$ & $2 \mathrm{M} 2$ & $2 \mathrm{M} 2$ & 68.42 .825 .6 & 67.32 .727 .1 & Yes & Yes \\
\hline 6 & $1 \mathrm{M} 2$ & $1 \mathrm{M} 1$ & $1 \mathrm{M} 2$ & $1 \mathrm{M} 2$ & $78.7-1.79 .7$ & $79-2.211 .1$ & Yes & Yes \\
\hline 7 & $3 \mathrm{M} 2$ & $2 \mathrm{M} 3$ & $3 \mathrm{M} 2$ & $3 \mathrm{M} 2$ & $80.7-2.114 .6$ & 80.70 .913 .6 & No & No \\
\hline 8 & 2L 2.5 & 2R2.5 & 2L1.5 & 1L2.5 & $82.6-0.918 .4$ & $83-0.718$ & Yes & Yes \\
\hline 9 & $3 \mathrm{M} 2$ & $2 \mathrm{M} 3$ & $2 \mathrm{M} 3$ & $3 \mathrm{M} 2$ & $79.4-1.312 .5$ & $82.3-0.811 .7$ & No & No \\
\hline 10 & 4L1.5 & 4L1.5 & 4L1.5 & $3 \mathrm{M} 3$ & 71.74 .730 .7 & 71.23 .230 .7 & Yes & Yes \\
\hline 11 & $1 \mathrm{M} 2$ & $1 \mathrm{M} 2$ & $1 \mathrm{M} 2$ & $1 \mathrm{M} 2$ & $87.9-2.716 .3$ & $86.2-2.216$ & Yes & Yes \\
\hline 12 & $3 \mathrm{M} 2$ & $2 \mathrm{M} 3$ & $3 \mathrm{M} 2$ & $3 \mathrm{M} 2$ & $78.9-1.714 .4$ & $78.2-1.314 .1$ & Yes & Yes \\
\hline 13 & $2 \mathrm{M} 3$ & $2 \mathrm{M} 3$ & $2 \mathrm{M} 3$ & $2 \mathrm{M} 3$ & 84.53 .533 .4 & 83.43 .129 .5 & Yes & No \\
\hline 14 & $3 \mathrm{M} 2$ & $3 \mathrm{M} 2$ & $2 \mathrm{M} 3$ & $3 \mathrm{M} 2$ & $81.5-1.915 .9$ & $81.3-1.315 .3$ & No & Yes \\
\hline 15 & $2 \mathrm{M} 2$ & $2 \mathrm{M} 2$ & $2 \mathrm{M} 3$ & $2 \mathrm{M} 2$ & $81.4-1.814 .9$ & $81.3-211.1$ & No & No \\
\hline 16 & $1 \mathrm{M} 2$ & $1 \mathrm{M} 2$ & $1 \mathrm{M} 2$ & $1 \mathrm{M} 2$ & $86.3-2.317 .3$ & $86-2.417 .7$ & Yes & Yes \\
\hline 17 & $2 \mathrm{M} 2$ & $2 \mathrm{M} 2$ & $2 \mathrm{M} 2$ & $2 \mathrm{M} 2$ & $83-311$ & $82.7-2.213 .1$ & Yes & No \\
\hline 18 & 3L1.5 & $3 \mathrm{M} 2$ & 3L1.5 & 3L1.5 & $70-1.411 .7$ & $76.6-2.713 .2$ & No & Yes \\
\hline 19 & $3 \mathrm{M} 2$ & $2 \mathrm{M} 3$ & $3 \mathrm{M} 2$ & $3 \mathrm{M} 2$ & $77.8-1.612 .8$ & $78.2-1.712$ & Yes & Yes \\
\hline 20 & 2L2.5 & 2M3 & 2L2.5 & 2L2.5 & $83.1-1.825 .4$ & $82.8-1.822 .1$ & Yes & No \\
\hline 21 & 3L1.5 & 3L1.5 & 3L1.5 & 3L1.5 & $72.1-1.413 .3$ & $72.7-1.513 .7$ & Yes & Yes \\
\hline 22 & $3 \mathrm{M} 2$ & $2 \mathrm{M} 3$ & $2 \mathrm{M} 3$ & $3 \mathrm{M} 2$ & $36.9-3.110 .7$ & $83.2-2.713 .1$ & No & Yes \\
\hline 23 & $1 \mathrm{M} 2$ & $1 \mathrm{M} 2$ & $1 \mathrm{M} 2$ & $1 \mathrm{M} 2$ & $84-2.415 .3$ & $84.2-0.9515 .8$ & Yes & Yes \\
\hline 24 & $3 \mathrm{M} 2$ & $3 \mathrm{M} 2$ & $3 \mathrm{M} 2$ & $3 \mathrm{M} 2$ & $73.3-1.712 .3$ & $74-3.212 .5$ & Yes & Yes \\
\hline 25 & 4L1.5 & $2 \mathrm{M} 3$ & 4L1.5 & 4L1.5 & $66.9-0.721$ & $73.3-0.819 .7$ & Yes & Yes \\
\hline 26 & $1 \mathrm{M} 2$ & $1 \mathrm{M} 2$ & $1 \mathrm{M} 2$ & $1 \mathrm{M} 2$ & $83-2.314$ & $82.8-0.814$ & Yes & Yes \\
\hline 27 & $1 \mathrm{M} 1$ & $1 \mathrm{M} 1$ & $1 \mathrm{M} 1$ & $1 \mathrm{M} 1$ & $80.7-29.8$ & $80.2-2.210 .1$ & Yes & Yes \\
\hline 28 & $3 \mathrm{M} 1$ & $3 \mathrm{M} 1$ & $1 \mathrm{M} 3$ & $3 \mathrm{M} 1$ & $79.6-1.716$ & 80.22 .315 .2 & Yes & No \\
\hline 29 & 2L2.5 & 2L2.5 & $2 \mathrm{M} 3$ & 2L2.5 & $84.3-2.317 .7$ & $84.2-2.215 .4$ & Yes & No \\
\hline 30 & $1 \mathrm{M} 2$ & $1 \mathrm{M} 2$ & $2 \mathrm{M} 1$ & $1 \mathrm{M} 2$ & $85.4-1.815 .5$ & $84.9-1.613 .3$ & No & No \\
\hline 31 & $1 \mathrm{M} 2$ & $1 \mathrm{M} 2$ & $1 \mathrm{M} 2$ & $1 \mathrm{M} 2$ & $85.9-1.415 .5$ & $86.2-1.315 .3$ & Yes & Yes \\
\hline 32 & $1 \mathrm{M} 2$ & $1 \mathrm{M} 2$ & $1 \mathrm{M} 2$ & $1 \mathrm{M} 2$ & $84.5-1.913$ & $84.2-1.411 .4$ & Yes & Yes \\
\hline 33 & $1 \mathrm{M} 1$ & $1 \mathrm{M} 1$ & 2M1 & $1 \mathrm{M} 1$ & $77.6-1.2+14.2$ & $78.2-1.713 .3$ & No & Yes \\
\hline 34 & $1 \mathrm{M} 2$ & $1 \mathrm{M} 2$ & $1 \mathrm{M} 2$ & $1 \mathrm{M} 2$ & $84.4-2.412 .7$ & $84.3-2.212 .3$ & Yes & Yes \\
\hline 35 & $1 \mathrm{M} 1$ & $1 \mathrm{M} 1$ & $2 \mathrm{M} 1$ & $1 \mathrm{M} 1$ & $83.6-2.415 .5$ & $83.3-0.715 .1$ & No & Yes \\
\hline 36 & 4L1.5 & $3 \mathrm{M} 3$ & $3 \mathrm{M} 3$ & 4L1.5 & 642.818 .7 & $66.6-2.717 .3$ & No & No \\
\hline 37 & 4L1.5 & 4L1.5 & 4L1.5 & 4L1.5 & $79-1.816 .5$ & 78.61 .316 .3 & Yes & Yes \\
\hline 38 & $1 \mathrm{M} 1$ & $1 \mathrm{M} 2$ & $1 \mathrm{M} 2$ & $1 \mathrm{M} 1$ & $83.7-2.316 .4$ & $81.3-3.111 .1$ & No & No \\
\hline 39 & 4L1.5 & $2 \mathrm{M} 3$ & $2 \mathrm{M} 3$ & 4L1.5 & $81.2-0.512 .7$ & $81-2.211 .2$ & No & No \\
\hline 40 & $3 \mathrm{M} 3$ & 2R2.5 & 2R2.5 & $3 \mathrm{M} 3$ & 77.11 .832 .4 & 77.41 .929 .1 & No & No \\
\hline 41 & 3M1 & 3M1 & 3M1 & $3 \mathrm{M} 1$ & $77.9-0.716 .8$ & $77-0.916 .3$ & Yes & Yes \\
\hline 42 & $2 \mathrm{M} 3$ & $2 \mathrm{M} 3$ & $2 \mathrm{M} 3$ & $2 \mathrm{M} 3$ & $78.9-0.821 .3$ & $78.5-119.1$ & Yes & Yes \\
\hline 43 & $1 \mathrm{M} 1$ & $1 \mathrm{M} 1$ & $1 \mathrm{M} 1$ & $1 \mathrm{M} 1$ & $83-2.412 .3$ & 81.92 .214 .1 & Yes & Yes \\
\hline 44 & $3 \mathrm{R} 2.5$ & $3 \mathrm{R} 2.5$ & $3 \mathrm{M} 3$ & $3 \mathrm{R} 2.5$ & $78.8-0.518 .4$ & $78.4-0.617 .1$ & Yes & Yes \\
\hline 45 & 4L1.5 & 4L1.5 & 4L1.5 & 4L1.5 & $80.2-215.3$ & $80-0.815$ & Yes & Yes \\
\hline 46 & 3L1.5 & 3L1.5 & 3L1.5 & 3L1.5 & 70.11 .512 .9 & 71.51 .311 .1 & No & No \\
\hline 47 & $3 \mathrm{M} 3$ & $3 \mathrm{M} 3$ & $3 \mathrm{M} 3$ & $3 \mathrm{M} 3$ & $74-2.111 .6$ & $77.2-3.213 .3$ & Yes & Yes \\
\hline 48 & $3 \mathrm{M} 1$ & 2M3 & $3 \mathrm{M} 1$ & $3 \mathrm{M} 1$ & $85.2-2.913 .6$ & $85.3-2.215 .1$ & Yes & Yes \\
\hline 49 & $1 \mathrm{M} 2$ & $1 \mathrm{M} 2$ & $1 \mathrm{M} 2$ & $1 \mathrm{M} 2$ & $82.2-2.214 .3$ & $83.3-2.514 .9$ & Yes & Yes \\
\hline 50 & 3L1.5 & $2 \mathrm{M} 2$ & 3L1.5 & 3L1.5 & 70.41 .511 .7 & 70.31 .412 .3 & Yes & Yes \\
\hline
\end{tabular}


Table 2. Coefficient of agreement between Visual and Spectrophotometric methods.

\begin{tabular}{|c|c|c|c|c|}
\hline & \multicolumn{2}{|c|}{ Spectrophotometer } & \multirow{2}{*}{ Total } & $\begin{array}{c}\text { Kappa } \\
\text { coefficient }\end{array}$ \\
\cline { 2 - 3 } & Did not agree & Agreed & & \\
\cline { 1 - 3 } Visual method & 0 & 8 & 8 & \multirow{2}{*}{0.213} \\
\cline { 1 - 1 } Did not agree & 8 & 34 & 42 & \\
\cline { 1 - 3 } Visual method & 8 & 42 & 50 & \\
\cline { 1 - 3 } Agreed & \multicolumn{2}{|c|}{} \\
\cline { 1 - 3 } Total & 8 & & \\
\hline
\end{tabular}

Table 3. Overall agreement between Visual and Spectrophotometer methods.

\begin{tabular}{|c|c|c|}
\hline Agreement & Frequency (\%) & P value of $\mathbf{z}$ test \\
\hline No & $14(28 \%)$ & \multirow{2}{*}{$0.001 * *$} \\
\cline { 1 - 2 } Yes & $36(72 \%)$ & \\
\hline Total & $50(100 \%)$ & \\
\hline
\end{tabular}

$* * \mathrm{p}<0.05$

Table 4. Overall agreement between Visual and Intraoral scanner methods.

\begin{tabular}{|c|c|c|}
\hline Agreement & Frequency (\%) & P value of $\mathbf{z}$ test \\
\hline No & $16(32 \%)$ & \multirow{3}{*}{$0.001 * *$} \\
\cline { 1 - 2 } Yes & $34(68 \%)$ & \\
\hline Total & $50(100 \%)$ & \\
\hline
\end{tabular}

$* * \mathrm{p}<0.05$

scanner methods (Table 1). Assessment of the repeatability of shade matching using spectrophotometer and the intraoral scanner method was done and compared to the visual method. Repeatability was evaluated by recognizing repeated measures from the same participant . As shown in Figure 3, The visual method carried by the sixth year dental students recorded the lowest repeatability in shade matching with matching observations of $81.5 \%$ and $(\mathrm{SD}=11.48 \%)$, followed by visual method by dentist with less than two years' experience $(83.8 \%$ - $\mathrm{SD}=7.02 \%)$ then visual method by prosthodontist $(84.16 \%$ - $\mathrm{SD}=5.31 \%)$ then, spectrophotometer $(93 \%$ - $\mathrm{SD}=4.02 \%)$, while the intraoral scanner gave the highest repeatability with $94 \%$ and $\mathrm{SD}=4.6 \%$.

There is statistical significant difference between Visual, spectrophotometer methods as well as between Visual, intraoral scanner methods $(\mathrm{P}=0.003, \mathrm{P}=0.002$ respectively). There is no statistical significant differences between spectrophotometer and intraoral scanner methods $(\mathrm{P}=0.64)$.

The coefficient of agreement (using Kappa coefficient) was used to compare of shades recorded by visual and spectrophotometric systems, Results showed that $($ Kappa coefficient $=0.214)$ indicating a fair agreement between the shades as done by these two methods [Table 2]. Z test for proportions was used to compare agreement between the visual and spectrophotometric method. Results showed high proportion of agreement "yes" and there was a statistically significant difference [ $\mathrm{Z}$ score was -4.1 and $\mathrm{P}$ value was $0.00245(\mathrm{P}<0.01)$ ] (Table 3). $Z$ test for proportions was used to compare the agreement between visual and intraoral scanner methods,results were statistically significant with high proportion of agreement "yes" [the Zscore was -2.9and $\mathrm{P}=$ $0.00651(\mathrm{P}<0.01)$.] (Table 4). The repeatability of visual shade matching as influenced by evaluator's experience was shown in (Figure 3), ANOVA test showed that the differences between the three groups were not statistically significant $(\mathrm{P}=0.526)$.

\section{Discussion}

The science of color is acombination of science and art.Visual matching using a shade guide is the most commonused method to record the teeth shade. It depends on the evaluator's visual perception. This method is easy and economicalthat compares teeth shade with a standard shade guide [28]. However, itdepends on many psychological and physiological factors and can vary according to surrounding environment $[16,17,29]$. An alternative method of shade recording is using instrumental color measurements as colorimeters, digital cameras, spectrophotometers and intraoral scanners [30]. As the teeth color are greatly influenced by the patient's age so, participant's age in this study was between 20 and 35 years [31].

Shade matching was taken in the middle third of the tooth because the incisal third usually shows some translucent areas or white spots, this may give a mixed colors that are difficult to be recorded by spectrophotometers [32] Also, the cervical third shade may change due to contrast of the gingiva.VITAEasyshadeintraoral spectrophotometer was used in this study, its probe is positioned on the tooth giving precise measurement in the form of $\mathrm{L}^{*} \mathrm{a}^{*} \mathrm{~b}^{*}$ values. Trios 3 intraoral scanner has confocal microscopy with 20 microns accuracy; it uses photo-imaging technique to scan the 
tooth [33]. There is great controversy regarding the repeatability of visual and instrumental methods. The null hypothesis that the tested methods for shade recording would have similar repeatability and that no alteration would be between their deviation records was rejected. The null hypothesis was rejected as shade matching using spectrophotometer or intraoral scanner was more repeatable than visual method, this was previously confirmed in other studies [4, 11, 12, 34-38]. Instrumental methods gave more accurate results and facilitating communication between dental professionals [39, [40]. Some studies showed that visual matching is more reliable than instrumental one [41, 42], Bahannan [21] reported that VITA Easy shade gave $80.4 \%$ of correct shade matches while visual shade guide records $36.3 \%$ of shade matches. Moreover, shade matching by Easyshade was more repeatable than the VITA classical shade guide was. Jarad et al. [43] investigated computer-based shade determination and found that it improves the dentist's capability to match the shade in a tough situation when it is difficult to assess a single tab to match the tooth, matching was $61.1 \%$ with computer while it was $41 \%$ in conventional method. Some studies recommended using both visual and instrumental methods to integrate each other achieving superior results $[44,45]$ but, the high price of these machines limits its spread in clinical practice [46]. Our result wasreflected on the percentage of agreement of shade selection between the visual and bothinstrumental methods (Tables 3 and 4). The percentage of agreement between visual and spectrophotometric method was $72 \%$, between visual and intraoral scanner method was $68 \%$, whichare statistically significant. Gómez-Polo et al. [47] showed a significant differences between visual method and spectrophotometricone, they found a high "value" agreement when compared to "chroma andhue". No significant differences in repeatability was found between VITA Easyshade spectrophotometer and Trios 3 intraoral scanner. Previous studies proved the same result where Easy shade accuracy where comparable to trios even in clinical situations $[48,49]$.

Yilmaz et al.[28] proved that no significant difference between instrumental and visual matching when carried out by an expert dentist. Theoretically, dentist's experience should affect shade determination because dental practice and repetition will allows reproducible and more accurate results over time. Many studies support this hypothesis $[9,16,18,50]$. However, other researches disprove it [20-23]. Our results also disagree with this rule, despite there is increase in repeatability percent from sixth year dental students to dentists with less than two years' experience to experienced prosthodontists, these differences were small with no statistically significant.

\section{Study limitations}

No time limit for each shade-matching session, which may lead to eye fatigue in visual method. No typical scanning technique has been recommended for shade matching using intraoral scanners, where factors as distance, scan angle and light source may affect results.

\section{Conclusion and Clinical Significance}

Within the limitations of this clinical study, the following conclusions were drawn:
1. Instrumental methods for shade selection using spectrophotometer or intraoral scannerwere more repeatable than the visual method.

2. Trios 3 intraoral scanner showed higher repeatability than Easy shade spectrophotometer, but the difference was statistically nonsignificant

3. Visual shade repeatability was influenced by the operator's experience but with no statistical significance difference between studied groups.

Further studies on larger sample size with the use of digital cameras available in the market for shade selection are recommended, also measuring color difference $(\mathrm{E})$ between different methods of shade selection is important.

\section{Declaration of patient consent}

All participants have given their written consent for their photos and other data to be published in the journal without identifying their names.

\section{Conflict of interest}

No conflicts of interest and No funding was received for the research that could have influenced its results.

\section{References}

[1]. Edelhoff D, Prandtner O, Saeidi Pour R, Liebermann A, Stimmelmayr M, Güth JF. Anterior restorations: The performance of ceramic veneers. Quintessence Int. 2018;49(2):89-101. Pubmed PMID: 29292405.

[2]. Yoon HI, Bae JW, Park JM, Chun YS, Kim MA, Kim M. A Study on Possibility of Clinical Application for Color Measurements of Shade Guides Using an Intraoral Digital Scanner. J Prosthodont. 2018 Aug;27(7):670-675. Pubmed PMID: 29377326.

[3]. Igiel C, Lehmann KM, Ghinea R, Weyhrauch M, Hangx Y, Scheller H, et al. Reliability of visual and instrumental color matching. J Esthet Restor Dent. 2017 Sep;29(5):303-308. Pubmed PMID: 28742283.

[4]. Kim-Pusateri S, Brewer JD, Davis EL, Wee AG. Reliability and accuracy of four dental shade-matching devices. J Prosthet Dent. 2009 Mar;101(3):1939. Pubmed PMID: 19231572.

[5]. A Guide to Understanding Color Communication-Xrite. Available from: https://www.Xrite.com. [Last accessed on 2021 April 08].

[6]. CIELAB Color Space-.Wikipedia. Available from: https:// en.n.wikipedia. org. [Last accessed on 2021 April 08].

[7]. Sharma G, Wu W, Dalal EN. The CIEDE2000 color-difference formula: Implementation notes, supplementary test data, and mathematical observations. Color Research \& Application: Endorsed by Inter-Society Color Council, The Colour Group (Great Britain), Canadian Society for Color, Color Science Association of Japan, Dutch Society for the Study of Color, The Swedish Colour Centre Foundation, Colour Society of Australia, Centre Français de la Couleur. 2005 Feb;30(1):21-30.

[8]. Pecho OE, Ghinea R, Alessandretti R, Pérez MM, Della Bona A. Visual and instrumental shade matching using CIELAB and CIEDE2000 color difference formulas. Dent Mater. 2016 Jan;32(1):82-92. Pubmed PMID: 26631341.

[9]. Clary JA, Ontiveros JC, Cron SG, Paravina RD. Influence of light source, polarization, education, and training on shade matching quality. J Prosthet Dent. 2016 Jul;116(1):91-7. Pubmed PMID: 26851189.

[10]. Lasserre JF, Pop-Ciutrila IS, Colosi HA. A comparison between a new visual method of colour matching by intraoral camera and conventional visual and spectrometric methods. J Dent. 2011 Dec;39 Suppl 3:e29-36. Pubmed PMID: 22101123.

[11]. Pohlen B, Hawlina M, Šober K, Kopač I. Tooth Shade-Matching Ability Between Groups of Students with Different Color Knowledge. Int J Prosthodont. 2016 Sep-Oct;29(5):487-92. Pubmed PMID: 27611754.

[12]. Paul SJ, Peter A, Rodoni L, Pietrobon N. Conventional visual vs spectrophotometric shade taking for porcelain-fused-to-metal crowns: a clinical comparison. Journal of Prosthetic Dentistry. 2004 Dec 1;92(6):577.

[13]. Kielbassa AM, Beheim-Schwarzbach NJ, Neumann K, Nat R, Zantner C. 
In vitro comparison of visual and computer-aided pre- and post-tooth shade determination using various home bleaching procedures. J Prosthet Dent. 2009 Feb;101(2):92-100. Pubmed PMID: 19167533.

[14]. Ahlholm P, Sipilä K, Vallittu P, Jakonen M, Kotiranta U. Digital Versus Conventional Impressions in Fixed Prosthodontics: A Review. J Prosthodont. 2018 Jan;27(1):35-41. Pubmed PMID: 27483210.

[15]. Gotfredsen K, Gram M, Ben Brahem E, Hosseini M, Petkov M, Sitorovic M. Effectiveness of shade measurements using a scanning and computer software system: a pilot study. Int J Oral Dent Health. 2015;1(008).

[16]. Della Bona A, Barrett AA, Rosa V, Pinzetta C. Visual and instrumental agreement in dental shade selection: three distinct observer populations and shade matching protocols. Dent Mater. 2009 Feb;25(2):276-81. Pubmed PMID: 19019420

[17]. Alshiddi IF, Richards LC. A comparison of conventional visual and spectrophotometric shade taking by trained and untrained dental students. Aust Dent J. 2015 Jun;60(2):176-81. Pubmed PMID: 25990070.

[18]. Capa N, Malkondu O, Kazazoglu E, Calikkocaoglu S. Evaluating factors that affect the shade-matching ability of dentists, dental staff members and laypeople. J Am Dent Assoc. 2010 Jan;141(1):71-6. Pubmed PMID: 20045824.

[19]. Seghi RR, Hewlett ER, Kim J. Visual and instrumental colorimetric assessments of small color differences on translucent dental porcelain. J Dent Res. 1989 Dec;68(12):1760-4. Pubmed PMID: 2600257.

[20]. Kröger E, Matz S, Dekiff M, Tran BL, Figgener L, Dirksen D. In vitro comparison of instrumental and visual tooth shade determination under different illuminants. J Prosthet Dent. 2015 Dec;114(6):848-55. Pubmed PMID: 26346420.

[21]. Bahannan SA. Shade matching quality among dental students using visual and instrumental methods. J Dent. 2014 Jan;42(1):48-52. Pubmed PMID: 24252802.

[22]. Poljak-Guberina R, Celebic A, Powers JM, Paravina RD. Colour discrimination of dental professionals and colour deficient laypersons. J Dent. 2011 Dec;39 Suppl 3:e17-22. Pubmed PMID: 21996337.

[23]. Nakhaei M, Ghanbarzadeh J, Amirinejad S, Alavi S, Rajatihaghi H. The Influence of Dental Shade Guides and Experience on the Accuracy of Shade Matching. J Contemp Dent Pract. 2016 Jan 1;17(1):22-6. Pubmed PMID: 27084858.

[24]. Miyajiwala JS, Kheur MG, Patankar AH, Lakha TA. Comparison of photographic and conventional methods for tooth shade selection: A clinical evaluation. J Indian Prosthodont Soc. 2017 Jul-Sep;17(3):273-281. Pubmed PMID: 28936042.

[25]. Ishihara S. Ishihara's test for color blindness. Concise ed. Tokyo: Kanehara \& Co, Ltd; 1993.

[26]. Celebić A, Stipetić J, Nola P, Petricević N, Papić M. Use of digital photographs for artificial tooth selection. Coll Antropol. 2004 Dec;28(2):857-63. Pubmed PMID: 15666621.

[27]. Veeraganta SK, Savadi RC, Baroudi K, Nassani MZ. Differences in tooth shade value according to age, gender and skin color: A pilot study. J Indian Prosthodont Soc. 2015 Apr-Jun;15(2):138-41. Pubmed PMID: 26929500.

[28]. Yılmaz B, Yuzugullu B, Cinar D, Berksun S. Effects of shade tab arrangement on the repeatability and accuracy of shade selection. J Prosthet Dent. 2011 Jun;105(6):383-6. Pubmed PMID: 21640239.

[29]. Jasinevicius TR, Curd FM, Schilling L, Sadan A. Shade-matching abilities of dental laboratory technicians using a commercial light source. J Prosthodont. 2009 Jan;18(1):60-3. Pubmed PMID: 19166550.

[30]. Choi JH, Park JM, Ahn SG, Song KY, Lee MH, Jung JY, et al. Comparative study of visual and instrumental analyses of shade selection. Journal of Wuhan University of Technology-Mater. Sci. Ed.. 2010 Feb 1;25(1):62-7.

[31]. Rodrigues S, Shetty SR, Prithviraj DR. An evaluation of shade differences between natural anterior teeth in different age groups and gender using commercially available shade guides. J Indian Prosthodont Soc. 2012 Dec;12(4):222-30. Pubmed PMID: 24293919.

[32]. Chu SJ. Use of a reflectance spectrophotometer in evaluating shade change resulting from tooth-whitening products. J Esthet Restor Dent. 2003;15 Suppl 1:S42-8. Pubmed PMID: 15000904

[33]. Lim JH, Park JM, Kim M, Heo SJ, Myung JY. Comparison of digital intraoral scanner reproducibility and image trueness considering repetitive experience. J Prosthet Dent. 2018 Feb;119(2):225-232. Pubmed PMID: 28689906.

[34]. Mehl A, Bosch G, Fischer C, Ender A. In vivo tooth-color measurement with a new $3 \mathrm{D}$ intraoral scanning system in comparison to conventional digital and visual color determination methods. Int J Comput Dent. 2017;20(4):343-361. Pubmed PMID: 29292410.

[35]. Brandt J, Nelson S, Lauer HC, von Hehn U, Brandt S. In vivo study for tooth colour determination-visual versus digital. Clin Oral Investig. 2017 Dec;21(9):2863-2871. Pubmed PMID: 28265772.

[36]. Moussaoui H, El Mdaghri M, Gouma A, Bennani B. Accuracy, repeatability and reproducibility of digital intraoral scanner for shade selection: current status of the literature. Oral Health Dental Sci. 2018;2(4):1-6.

[37]. Khurana R, Tredwin CJ, Weisbloom M, Moles DR. A clinical evaluation of the individual repeatability of three commercially available colour measuring devices. Br Dent J. 2007 Dec 22;203(12):675-80. Pubmed PMID: 18084212.

[38]. Parameswaran V, Anilkumar S, Lylajam S, Rajesh C, Narayan V. Comparison of accuracies of an intraoral spectrophotometer and conventional visual method for shade matching using two shade guide systems. J Indian Prosthodont Soc. 2016 Oct-Dec;16(4):352-358. Pubmed PMID: 27746599.

[39]. Pimental W, Tiossi R. Comparison between visual and instrumental methods for natural tooth shade matching. Gen Dent. 2014 Nov-Dec;62(6):47-9. Pubmed PMID: 25369386.

[40]. Alshethri SE. Evaluation of color changes in the Vitapan Classical Shade Guide after disinfection. Oper Dent. 2014 May-Jun;39(3):317-24. Pubmed PMID: 24147748.

[41]. Hugo B, Witzel T, Klaiber B. Comparison of in vivo visual and computeraided tooth shade determination. Clin Oral Investig. 2005 Dec;9(4):24450. Pubmed PMID: 16215749.

[42]. Ratzmann A, Treichel A, Langforth G, Gedrange T, Welk A. Experimental investigations into visual and electronic tooth color measurement. Biomed Tech (Berl). 2011 Apr;56(2):115-22. Pubmed PMID: 21453129.

[43]. Jarad FD, Russell MD, Moss BW. The use of digital imaging for colour matching and communication in restorative dentistry. Br Dent J. 2005 Jul 9;199(1):43-9; discussion 33. Pubmed PMID: 16003426

[44]. Chu SJ, Trushkowsky RD, Paravina RD. Dental color matching instruments and systems. Review of clinical and research aspects. J Dent. 2010;38 Suppl 2:e2-16. Pubmed PMID: 20621154

[45]. Oh WS, Koh IW, O'Brien WJ. Estimation of visual shade matching errors with 2 shade guides. Quintessence Int. 2009 Nov-Dec;40(10):833-6. Pubmed PMID: 19898714

[46]. Ortolan SM, Persic S, Celebic A, Mehulic K. Comparison of time consumption and color matching results of different dental occupational groups. Int J Prosthodont. 2013 Sep-Oct;26(5):478-86. Pubmed PMID: 23998147.

[47]. Gómez-Polo C, Gómez-Polo M, Celemin-Vińuela A, Martínez Vázquez De Parga JA. Differences between the human eye and the spectrophotometer in the shade matching of tooth colour. J Dent. 2014 Jun;42(6):742-5. Pubmed PMID: 24140995.

[48]. Liberato WF, Barreto IC, Costa PP, de Almeida CC, Pimentel W, Tiossi R. A comparison between visual, intraoral scanner, and spectrophotometer shade matching: A clinical study. J Prosthet Dent. 2019 Feb;121(2):271275. Pubmed PMID: 30722987.

[49]. Ebeid K, Sabet A, Della Bona A. Accuracy and repeatability of different intraoral scanners on shade determination. J Esthet Restor Dent. 2020 Nov 23. Pubmed PMID: 33227179.

[50]. Capa N, Malkondu O, Kazazoglu E, Calikkocaoglu S. Evaluating factors that affect the shade-matching ability of dentists, dental staff members and laypeople. J Am Dent Assoc. 2010 Jan;141(1):71-6. Pubmed PMID: 20045824. 